\title{
DERMATOPHYTE SUSCEPTIBILITIES TO ANTIFUNGAL AZOLE AGENTS TESTED IN VITRO BY BROTH MACRO AND MICRODILUTION METHODS
}

\begin{abstract}
SUMMARY
The in vitro susceptibility of dermatophytes to the azole antifungals itraconazole, fluconazole and ketoconazole was evaluated by broth macro and microdilution methods, according to recommendations of the CLSI, with some adaptations. Twenty nail and skin clinical isolates, four of Trichophyton mentagrophytes and 16 of T. rubrum were selected for the tests. Itraconazole minimal inhibitory concentrations (MIC) varied from $<0.03$ to $0.25 \mu \mathrm{g} / \mathrm{mL}$ in the macrodilution and from $<0.03$ to $0.5 \mu \mathrm{g} / \mathrm{mL}$ in the microdilution methods; for fluconazole, MICs were in the ranges of 0.5 to $64 \mu \mathrm{g} / \mathrm{mL}$ and 0.125 to $16 \mu \mathrm{g} / \mathrm{mL}$ by the macro and microdilution methods, respectively, and from $<0.03$ to $0.5 \mu \mathrm{g} / \mathrm{mL}$ by both methods for ketoconazole. Levels of agreement between the two methods ( \pm one dilution) were $70 \%$ for itraconazole, $45 \%$ for fluconazole and $85 \%$ for ketoconazole. It is concluded that the strains selected were inhibited by relatively low concentrations of the antifungals tested and that the two methodologies are in good agreement especially for itraconazole and ketoconazole.
\end{abstract}

KEYWORDS: Antifungal agents; Dermatophytes; Susceptibility.

\section{INTRODUCTION}

The prevalence of human fungal diseases and the development of new antifungal agents has focused interest on susceptibility tests emphasizing the necessity to develop reproducible standardized methods. Solutions to problems in the standardization of existing methods have been already proposed ${ }^{13}$. The first related document (M38-A) published in 2002 by the former NCCLS (National Committee for Clinical Laboratory Standards), currently CLSI (Clinical and Laboratory Standards Institute), dealing with the standardization of susceptibility tests in filamentous fungi did not include dermatophytes ${ }^{4}$.

More recent publications discuss the importance of standardized tests to evaluate susceptibility profiles of different species, dermatophytes included, utilizing methods recommended by the reference center. In addition, it will be possible to characterize in vitro resistant strains to antifungals as well as compare optimal susceptibility testing conditions suggested by different investigators ${ }^{8,9,10,11,15,18,19,20}$. Recent studies with interesting results have been conducted by BARROS et al..$^{1,2,3}$ aiming to establish a standard technique to test susceptibility of dermatophytes to antifungal drugs.

In the present report, the in vitro susceptibilities of Trichophyton rubrum and T. mentagrophytes, two of the most frequently isolated dermatophytes, to the azoles itraconazole, fluconazole and ketoconazole were tested by the broth macro and microdilution methods as recommended by document M38- $\mathrm{A}^{4}$.

\section{MATERIALS AND METHODS}

A total of 20 clinical isolates from nails and skin (four of T. rubrum and 16 of T. mentagrophytes) maintained in Sabouraud dextrose agar, at room temperature, until tested were included in this study ${ }^{22}$. Candida parapsilosis ATCC 22019 was the reference strain. The antifungals tested were itraconazole (Janssen, Beerse, Belgium), fluconazole (Pfizer, Sandwich, UK), and ketoconazole (Janssen Pharmaceutica, Titusville). Ketoconazole and itraconazole were diluted in dimethylsulfoxide (Vetec, Rio de Janeiro, Brazil) and fluconazole in sterile distilled water, and kept at $-20{ }^{\circ} \mathrm{C}$ until used. The antifungal final concentrations were 0.5 to $64 \mu \mathrm{g} / \mathrm{mL}$ for fluconazole and 0.03 to $16 \mu \mathrm{g} / \mathrm{mL}$ for both itraconazole and ketoconazole. The culture medium was RPMI-1640 broth (GIBCO BRL) containing L-glutamine, without sodium bicarbonate, supplemented with $2 \%$ glucose and buffered by 0.165 M MOPS (3-N-morpholine-propane sulfonic acid) (UBS, AG), $\mathrm{pH} 7.0$.

The MICs for the three drugs were determined both by broth macro and microdilution methods, according to the protocol in M38- $\mathrm{A}^{4}$ for filamentous fungi with some modifications, as described below ${ }^{12,20,21}$.

Dermatophyte strains were subcultured on potato dextrose agar (PDA) slants and incubated at $30{ }^{\circ} \mathrm{C}$ for seven days. After this period the tubes were flooded with $2 \mathrm{~mL}$ of sterile physiological saline (0.85\%), the conidia gently removed from the culture surface with the help of a sterile swab and transferred to a sterile conical tube, the final volume 


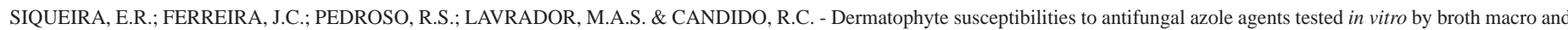
microdilution methods. Rev. Inst. Med. trop. S. Paulo, 50(1): 1-5, 2008.

being adjusted to $5 \mathrm{~mL}$ with saline. The resulting mixture of conidia and hyphal fragments was vortex mixed for 15 seconds and the heavy particles allowed to settle for five minutes. The resulting suspension was counted in a Neubauer chamber and standardized to concentrations of $1 \times 10^{6}$ to $5 \times 10^{6}$ conidia/mL. This suspension was further diluted 1:100 with RPMI-1640 broth to final concentrations of $1 \times 10^{4}$ to $5 \times 10^{4}$ conidia/mL.

For the broth macrodilution method, $900 \mu \mathrm{L}$ of the final conidia suspensions were mixed with $100 \mu \mathrm{L}$ of the test drug in 12x75 mm test tubes and incubated at $30{ }^{\circ} \mathrm{C}$ for seven days. The positive control tube contained $900 \mu \mathrm{L}$ of conidial suspension plus $100 \mu \mathrm{L}$ of RPMI 1640, and the negative one contained $1 \mathrm{~mL}$ of RPMI 1640 only. The smallest drug concentration inhibiting microbial growth by $50 \%$ was identified as the minimal inhibitory concentration (MIC). Flat-bottom microdilution plates containing 96 wells were employed for the broth microdilution method. To each well containing $100 \mu \mathrm{L}$ of the drug dilution to be tested, were added $100 \mu \mathrm{L}$ of the final conidia suspension. Growth positive control was the well containing $100 \mu \mathrm{L}$ of the inoculum suspension and $100 \mu \mathrm{L}$ of the RPMI only and the negative control was a well containing $200 \mu \mathrm{L}$ of RPMI 1640 .

The correlation analysis between MICs for each drug and microorganism was established by comparing the results in the macro and microdilution methods. The values were considered equivalent when both MICs were equal or differed by one dilution (reference value \pm one dilution). Agreement percentages, meaning the percentage of the total compared results obtained in the two methods considered as being equivalent, were calculated based on the definition of equivalent results ${ }^{17,18}$.
MIC values for antifungal drugs obtained in the two methods were compared by using the two-tailed signal test ${ }^{14}$, at significance level of 0.05 .

\section{RESULTS}

Itraconazole MIC ranges were $<0.03 \mu \mathrm{g} / \mathrm{mL}$ to $0.25 \mu \mathrm{g} / \mathrm{mL}$ by macrodilution and $<0.03$ to $0.5 \mu \mathrm{g} / \mathrm{mL}$ by the microdilution method (Table 1). The agreement index between the two methods was 70\% (Table 2). In both methods $\mathrm{MIC}_{50}$ (inhibition of $50 \%$ of the isolates) was $0.03 \mu \mathrm{g} / \mathrm{mL}$, but $\mathrm{MICs}_{90}$ (inhibition of $90 \%$ of the isolates) were, respectively, 0.125 and $0.25 \mu \mathrm{g} / \mathrm{mL}$ in the macro and microdilution.

For fluconazole, MICs varied from 0.5 to $64 \mu \mathrm{g} / \mathrm{mL}$ in macrodilution and from 0.125 to $16 \mu \mathrm{g} / \mathrm{mL}$ in the micro method. Within one dilution the agreement index for the two methodologies was $45 \%$ (Table 2). $\mathrm{MICs}_{50}$ were respectively, 1 and $0.5 \mu \mathrm{g} / \mathrm{mL}$ and $\mathrm{MICs}_{90} 16$ and $4 \mu \mathrm{g} / \mathrm{mL}$, in macro and microdilutions. MIC values for fluconazole in the macrodilution method were higher in $75 \%$ of the strains tested. The MIC variation for ketoconazole was the same in both methods, < 0.03 to $0.5 \mu \mathrm{g} / \mathrm{mL}$ (Table 1 ) and the agreement index $85 \%$ within one dilution (Table 2). The values for $\mathrm{MICs}_{50}$ were 0.06 and $0.03 \mu \mathrm{g} / \mathrm{mL}$, respectively, for macro and microdilution and $\mathrm{MIC}_{90}$ was the same, $0.125 \mu \mathrm{g} / \mathrm{mL}$ in both methods.

For itraconazole and ketoconazole there were no significant differences when the two methods were used ( $p>0.05$ ). However, the difference between macro and microdilution was significant for fluconazole ( $p=0.0003)$.

Table 1

In vitro susceptibility of 20 dermatophytes isolates to itraconazole, fluconazole and ketoconazole determined by broth macro and micro dilution methods

\begin{tabular}{|c|c|c|c|c|c|c|}
\hline & \multicolumn{2}{|c|}{ Itraconazole } & \multicolumn{2}{|c|}{$\begin{array}{c}\text { MIC } \\
\text { Fluconazole }\end{array}$} & \multicolumn{2}{|c|}{ Ketoconazole } \\
\hline & $\begin{array}{l}\text { Macrodilution } \\
\quad(\mu \mathrm{g} / \mathrm{mL})\end{array}$ & $\begin{array}{l}\text { Microdilution } \\
\quad(\mu \mathrm{g} / \mathrm{mL})\end{array}$ & $\begin{array}{l}\text { Macrodilution } \\
\quad(\mu \mathrm{g} / \mathrm{mL})\end{array}$ & $\begin{array}{l}\text { Microdilution } \\
\quad(\mu \mathrm{g} / \mathrm{mL})\end{array}$ & $\begin{array}{l}\text { Macrodilution } \\
\quad(\mu \mathrm{g} / \mathrm{mL})\end{array}$ & $\begin{array}{l}\text { Microdilution } \\
\quad(\mu \mathrm{g} / \mathrm{mL})\end{array}$ \\
\hline T. mentagrophytes 1 & $<0.03$ & $<0.03$ & 16 & 4.0 & 0.125 & 0.03 \\
\hline T. mentagrophytes 2 & 0.25 & 0.06 & 64 & 16.0 & 0.5 & 0.5 \\
\hline T. mentagrophytes 3 & $<0.03$ & $<0.03$ & 16 & 4.0 & 0.06 & 0.03 \\
\hline T. mentagrophytes 4 & 0.03 & $<0.03$ & 2.0 & 0.5 & 0.03 & $<0.03$ \\
\hline T. rubrum 1 & 0.06 & 0.25 & 4.0 & 4.0 & 0.125 & 0.125 \\
\hline T. rubrum 2 & 0.03 & 0.125 & 1.0 & 0.25 & 0.125 & 0.125 \\
\hline T. rubrum 3 & $<0.03$ & $<0.03$ & 1.0 & 0.125 & 0.125 & 0.03 \\
\hline T. rubrum 4 & 0.125 & 0.25 & 8.0 & 8.0 & 0.25 & 0.25 \\
\hline T. rubrum 5 & $<0.03$ & 0.03 & 0.5 & 0.125 & 0.03 & $<0.03$ \\
\hline T. rubrum 6 & 0.125 & 0.5 & 2.0 & 1.0 & 0.06 & $<0.03$ \\
\hline T. rubrum 7 & 0.03 & 0.03 & 1.0 & 0.125 & 0.03 & $<0.03$ \\
\hline T. rubrum 8 & 0.125 & 0.06 & 8.0 & 0.5 & 0.125 & 0.03 \\
\hline T. rubrum 9 & $<0.03$ & 0.25 & 1.0 & 1.0 & 0.06 & 0.125 \\
\hline T. rubrum 10 & 0.03 & $<0.03$ & 1.0 & 0.25 & $<0.03$ & $<0.03$ \\
\hline T. rubrum 11 & $<0.03$ & $<0.03$ & 0.5 & 0.25 & $<0.03$ & $<0.03$ \\
\hline T. rubrum 12 & 0.03 & 0.03 & 1.0 & 0.5 & $<0.03$ & $<0.03$ \\
\hline T. rubrum 13 & 0.03 & $<0.03$ & 1.0 & 0.5 & $<0.03$ & $<0.03$ \\
\hline T. rubrum 14 & $<0.03$ & 0.5 & 1.0 & 1.0 & 0.06 & 0.03 \\
\hline T. rubrum 15 & 0.125 & 0.125 & 2.0 & 2.0 & 0.03 & 0.03 \\
\hline T. rubrum 16 & 0.125 & 0.06 & 1.0 & 0.25 & 0.03 & $<0.03$ \\
\hline
\end{tabular}




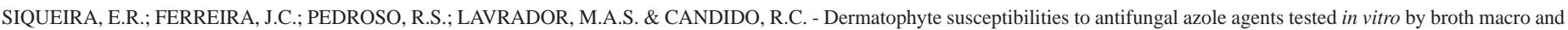
microdilution methods. Rev. Inst. Med. trop. S. Paulo, 50(1): 1-5, 2008.

Table 2

Agreement percentage between antifungal MICs in 20 dermatophytes strains obtained with macro- and microdilution methods.

\begin{tabular}{|c|c|c|c|c|c|c|c|c|c|c|}
\hline \multirow[t]{2}{*}{ Species (no. of strains tested) } & \multirow[t]{2}{*}{$\begin{array}{l}\text { Antifungal } \\
\text { agents }^{\mathrm{a}}\end{array}$} & \multicolumn{7}{|c|}{$\begin{array}{l}\text { No. of isolates for which MICs determined by micro } \\
\text { and macrodilution were different by the following dilutions }\end{array}$} & \multicolumn{2}{|c|}{ \% agreement } \\
\hline & & $\leq 3$ & 2 & 1 & 0 & 1 & 2 & $\geq 3$ & \pm 1 & \pm 2 \\
\hline \multirow[t]{3}{*}{ T. rubrum (16) } & ITZ & 0 & 0 & 2 & 8 & 1 & 3 & 2 & 68.7 & 87.5 \\
\hline & FCZ & 3 & 4 & 4 & 5 & 0 & 0 & 0 & 56.2 & 81.2 \\
\hline & KTZ & 0 & 2 & 2 & 11 & 1 & 0 & 0 & 87.5 & 100.0 \\
\hline \multirow[t]{3}{*}{ T. mentagrophytes (4) } & ITZ & 0 & 1 & 0 & 3 & 0 & 0 & 0 & 75.0 & 100.0 \\
\hline & FCZ & 0 & 4 & 0 & 0 & 0 & 0 & 0 & 0.0 & 100.0 \\
\hline & KTZ & 0 & 1 & 2 & 1 & 0 & 0 & 0 & 75.0 & 100.0 \\
\hline \multirow[t]{3}{*}{ Total (20) } & ITZ & 0 & 1 & 2 & 11 & 1 & 3 & 2 & 70.0 & 90.0 \\
\hline & FCZ & 3 & 8 & 4 & 5 & 0 & 0 & 0 & 45.0 & 85.0 \\
\hline & KTZ & 0 & 3 & 4 & 12 & 1 & 0 & 0 & 85.0 & 100.0 \\
\hline
\end{tabular}

${ }^{a}$ KTZ, ketoconazole; FCZ, fluconazole; ITZ, itraconazole.

\section{DISCUSSION}

Broth macro and microdilution methods were used in many studies to compare yeast susceptibilities in vitro. However, studies with filamentous fungi are scarce.

According to SANTOS et $a .^{20}$, a reproducible standardized susceptibility test is the first step in securing the reliability of these tests in the clinical laboratory and to proceed in studies correlating MICs and clinical outcomes. In recent years several publications described adapted or modified susceptibility tests based on $\mathrm{CLSI}^{4}$ and EUCAST $^{7}$ recommendations. However, the variation in the conditions employed and controversial results strongly points to the necessity of further collaborative studies ${ }^{3,8,9,10}$. Recent studies by BARROS et al. ${ }^{1,2,3}$ gave significant contributions concerning standardization of antifungal susceptibility tests in dermatophyte fungi. They addressed important factors that influence test reproducibility and reliability, as inoculum size, end-point determinations, incubation periods and temperatures, and visualization of growth inhibition.

In this study, we compared broth macro and microdilution methods to determine the in vitro susceptibilities of $T$. rubrum and $T$. mentagrophytes to three azole drugs, itraconazole, fluconazole and ketoconazole, that are frequently used in dermatophytosis treatment. Following the CLSI protocol (standard M38-A) ${ }^{4}$, with some adaptations $^{12}$ the tests were performed with 7-day incubations at $30{ }^{\circ} \mathrm{C}$ and inocula consisting only of microconidia as recommended. Recent studies have demonstrated that these structures have a higher susceptibility to antifungal drugs than hyphal fragments ${ }^{20}$. In addition, it was also shown that removal of hyphal fragments from microconidia inocula is more efficient by using a sterile filter (pore diameter $8 \mu \mathrm{m}$ ) than the procedure indicated in the CLSI protocol ${ }^{20}$. According to BARROS et al. ${ }^{1}$, the procedure of sterile filtering removes the majority of the hyphae, producing inocula composed mainly of spores. However, in this study microconidia were predominant and counted in a Neubauer chamber. Only in unusual conditions scarce hyphal fragments were present in the suspension. Another important factor is that the susceptibility tests should be made with recently isolated dermatophytes, when they are abundant conidia producers.

The results in Tables 1 and 2 show that itraconazole was a good in vitro growth inhibitor, with the lowest MIC ranges among the drugs tested, including $\mathrm{MIC}_{50}$ and $\mathrm{MIC}_{90}$. These results confirm values in the literature ${ }^{3,8,9,10,11,20}$. The highest MIC values in this study were for fluconazole. PUJOL et al. ${ }^{19}$ studying T. rubrum and T. mentagrophytes reported MIC values for fluconazole of 4 to $8 \mu \mathrm{g} / \mathrm{mL}$ and 8 to $128 \mu \mathrm{g} /$ $\mathrm{mL}$ for the two strains, respectively. Both determinations were made by the microdilution method and they are higher than the values reported here for T. mentagrophytes although the number of samples was small, about half the number studied by PUJOL et al. ${ }^{19}$. MIC values slightly higher were found by FERNÁNDEZ-TORRES et al. ${ }^{9}$, SANTOS \& HAMDAN $^{21}$ and SANTOS et al. ${ }^{20}$. The higher values obtained for $T$. mentagrophytes could not be confirmed in this study due to the small number of isolates but the values presented in Table 1 show what seems to be a trend. Also, a study with a large number of strains showed significant differences in $\mathrm{MIC}_{50}$ and $\mathrm{MIC}_{90}$ values in fluconazole susceptibility tests of T. mentagrophytes and T. rubrum ${ }^{9}$.

Ketoconazole was very active against both strains tested as shown by the MIC determinations, which justifies its wide therapeutic application not only because of activity but also in terms of price when compared to fluconazole and itraconazole. Ketoconazole MIC values reported by PUJOL et al. ${ }^{19}, 0.5$ to $2 \mu \mathrm{g} / \mathrm{mL}$, are somewhat higher than the ones in this study, but again the test different conditions should be considered.

The highest intermethod percentage agreement (Table 2) was 85\% for ketoconazole, considering \pm one dilution. In contrast, in a majority of isolates (75\%), fluconazole had higher MIC values when macrodilution was compared to microdilution. This azole was also the drug showing the lowest agreement percentage (45\%) in the conditions of the test. BARROS et al. ${ }^{2}$ claim that the visualization of growth inhibition could be confused with fungi poor growth in microdilution wells, indicating a false susceptibility profile for a given agent, which does not happen in macrodilution. Nevertheless, when we verified the 


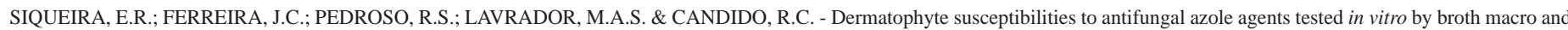
microdilution methods. Rev. Inst. Med. trop. S. Paulo, 50(1): 1-5, 2008.

MICs in both methodologies, we found values of $\leq 16 \mu \mathrm{g} / \mathrm{mL}$ in $100 \%$ of the isolates by microdilution method, and in $95 \%$ of them when they were evaluated by macrodilution. Despite the statistical significant difference $(p<0.05$ ), the use of the two methodologies should be further explored since in vitro reference values for susceptibility or resistance to fluconazole in dermatophytes are not existent. Standardization of the test conditions, as inoculum size, incubation period and temperature, will probably eliminate or attenuate the discrepancies. However, if equivalence is admitted in differences of \pm two dilutions, according to other studies ${ }^{6,18,19}$ the agreement index of the two methodologies for fluconazole will be considerably higher (85\%). However, more studies may be necessary, including a higher number of isolates.

Great progress has been achieved in the standardization of in vitro antifungal susceptibility tests. However, correlation of in vivo and in vitro studies are still lacking and they are fundamental to clinical analysis and interpretation of the results as well as for determining breakpoints. Evaluation of the results obtained for susceptibility and resistance is greatly improved when breakpoints are determined.

Statistical analysis pointed out that the two methodologies could be applied to determine Trichophyton susceptibility to itraconazole and ketoconazole. However, for fluconazole, results must be carefully analyzed, because MICs values obtained by the macrodilution method were higher than those obtained for microdilution in $75 \%$ of the isolates studied. Similar results has been observed in certain species, specially yeasts, where the agreement index of different methods is influenced by drug-organism combination ${ }^{5,16}$.

Thus, it is concluded that the majority of strains in the study were inhibited by relatively low concentrations of the antifungals tested. Broth macro and microdilution methods can be used for evaluating Trichophyton susceptibility to itraconazole and ketoconazole, but further studies must be conducted in vitro to analyze susceptibility to fluconazole.

\section{RESUMO}

\section{Suscetibilidade in vitro de dermatófitos a azóis pelos métodos macro e microdiluição em caldo}

Foi avaliada a suscetibilidade in vitro de dermatófitos aos antifúngicos itraconazol, fluconazol e cetoconazol, pelos métodos macro e microdiluição em caldo, de acordo com as recomendações do CLSI, com algumas modificações. Foram estudados 20 isolados clínicos de lesões de unha e pele, sendo quatro Trichophyton mentagrophytes e 16 T. rubrum. A concentração inibitória mínima (CIM) para itraconazol variou de < 0,03 a 0,25 $\mu \mathrm{g} / \mathrm{mL}$ pelo método da macrodiluição, e de < 0,03 a $0,5 \mu \mathrm{g} / \mathrm{mL}$ pela microdiluição em caldo; de 0,5 a $64 \mu \mathrm{g} / \mathrm{mL}$ e de 0,125 a $16 \mu \mathrm{g} / \mathrm{mL}$ para fluconazol, respectivamente, pela macro e microdiluição; e de $<0,03$ a $0,5 \mu \mathrm{g} / \mathrm{mL}$ por ambos os métodos para cetoconazol. A concordância entre os dois métodos (considerando \pm uma diluição) foi de $70 \%$ para itraconazol, $45 \%$ para fluconazol e $85 \%$ para cetoconazol. Conclui-se que os isolados estudados foram inibidos por concentrações relativamente baixas dos antifúngicos testados, e os dois métodos apresentam boa concordância, especialmente para itraconazol e cetoconazol.

\section{REFERENCES}

1. BARROS, M.E.S.; SANTOS, D.A. \& HAMDAN, J.S. - Antifungal susceptibility testing of Trichophyton rubrum by E-test. Arch. dermatol. Res., 299: 107-109, 2007.

2. BARROS, M.E.S.; SANTOS, D.A. \& HAMDAN, J.S. - Evaluation of susceptibility of Trichophyton mentagrophytes and Trichophyton rubrum clinical isolates to antifungal drugs using a modified CLSI microdilution method (M38-A). J. med. Microbiol., 56: 514-518, 2007.

3. BARROS, M.E.S.; SANTOS, D.A. \& HAMDAN, J.S. - In vitro methods for antifungal susceptibility testing of Trichophyton spp. Mycol. Res., 110(pt. 11): 1355-1360, 2006.

4. CLSI/Clinical and Laboratory Standards Institute - Reference method for broth dilution antifungal susceptibility testing of conidium-forming filamentous fungi. Wayne, 2002. (Approved Standard M38-A).

5. COLOMBO, A.L.; BARCHIESI, F.; McGOUGH, D.A. \& RINALDI, M.G. - Comparison of E-test and National Committee for Clinical Laboratory Standards broth macrodilution method for azole antifungal susceptibility testing. J. clin. Microbiol., 33: 535-540, 1995.

6. ESPINEL-INGROFF, A.; KISH Jr., C.W.; KERKERING, T.M. et al. - Collaborative comparison of broth macrodilution and microdilution antifungal susceptibility tests. J. clin. Microbiol., 30: 3138-3145, 1992.

7. EUCAST/European Committee on Antimicrobial Susceptibility Testing - Method for the determination of minimum inhibitory concentration by broth dilution of fermentative yeast. Clin. Microbiol. Infect., 9(8): i-viii, 2003.

8. FERNÁNDEZ-TORRES, B.; CABAÑES, F.J.; CARRILLO-MUÑOZ, A.J. et al. Collaborative evaluation of optimal antifungal susceptibility testing conditions for dermatophytes. J. clin. Microbiol., 40: 3999-4003, 2002.

9. FERNÁNDEZ-TORRES, B.; CARRILLO, A.J.; MARTIN, E. et al. - In vitro activities of 10 antifungal drugs against 508 dermatophyte strains. Antimicrob. Agents Chemother., 45: 2524-2528, 2001.

10. GHANNOUM, M.A.; CHATURVEDI, V.; ESPINEL-INGROFF, A. et al. - Intra- and interlaboratory study of a method for testing the antifungal susceptibilities of dermatophytes. J. clin. Microbiol., 42: 2977-2979, 2004.

11. JESSUP, C.J.; WARNER, J.; ISHAM, N.; HASAN, I. \& GHANNOUM, M.A. - Antifungal susceptibility testing of dermatophytes: establishing a medium for inducing conidial growth and evaluation of susceptibility of clinical isolates. J. clin. Microbiol., 38: 341-344, 2000.

12. KRAKHECKE, A.G.; AFONSO, E.; FERREIRA, J.C. \& CANDIDO, R.C. - In vitro susceptibility testing of Microsporum gypseum isolated from healthy cattle and soil samples against itraconazole, terbinafine, fluconazole and topical veterinarian drugs. Mycopathologia, 159: 377-380, 2005.

13. LLOP, C.; PUJOL, I.; AGUILAR, C. et al. - Comparison of three methods of determining MICs for filamentous fungi using different end point criteria and incubation periods. Antimicrob. Agents Chemother., 44: 239-242, 2000.

14. McPHERSON, G. - Statistics in scientific investigation: its basis, application, and interpretation. New York, Springer Verlag, 1990.

15. MELETIADIS, J.; MEIS, J.F.; MOUTON, J.W.; DONNELLY, J.P. \& VERWEIJ, P.E. Comparison of NCCLS and 3-(4,5-dimethyl-2-thiazyl)-2,5-diphenyl-2H-tetrazolium bromide (MTT) methods of in vitro susceptibility testing of filamentous fungi and development of a new simplified method. J. clin. Microbiol., 38: 2949-2954, 2000.

16. PEDROSO, R.S.; FERREIRA, J.C. \& CANDIDO, R.C. - In vitro susceptibility to antifungal agents of environmental Cryptococcus spp. isolated in the city of Ribeirão Preto, São Paulo, Brazil. Mem. Inst. Oswaldo Cruz, 101: 239-243, 2006. 


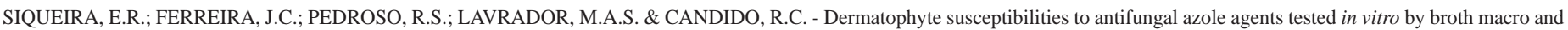
microdilution methods. Rev. Inst. Med. trop. S. Paulo, 50(1): 1-5, 2008.

17. PFALLER, M.A. \& BARRY, A.L. - Evaluation of a novel colorimetric broth microdilution method for antifungal susceptibility testing of yeast isolates. J. clin. Microbiol., 32: 1992-1996, 1994.

18. PFALLER, M.A.; MESSER, S.A.; MILLS, K. \& BOLMSTROM, A. - In vitro susceptibility testing of filamentous fungi: comparison of E-test and reference microdilution methods for determining itraconazole MICs. J. clin. Microbiol., 38: 3359-3361, 2000.

19. PUJOL, I.; CAPILLA, J.; FERNÁNDEZ-TORRES, B.; ORTONEDA, M. \& GUARRO, J. - Use of the sensititre colorimetric microdilution panel for antifungal susceptibility testing of dermatophytes. J. clin. Microbiol., 40: 2618-2621, 2002.
20. SANTOS, D.A.; BARROS, M.E.S. \& HAMDAN, J.S. - Establishing a method of inoculum preparation for susceptibility testing of Trichophyton rubrum and Trichophyton mentagrophytes. J. clin. Microbiol., 44: 98-101, 2006.

21. SANTOS, D.A. \& HAMDAN, J.S. - Evaluation of broth microdilution antifungal susceptibility testing conditions for Trichophyton rubrum. J. clin. Microbiol., 43: 1917-1920, 2005

22. SIQUEIRA, E.R.; FERREIRA, J.C.; MAFFEI, C.M.L. \& CANDIDO, R.C. - Ocorrência de dermatófitos em amostras de unhas, pés e mãos coletadas de estudantes universitários. Rev. Soc. bras. Med. trop., 39: 269-271, 2006.

Received: 31 January 2007

Accepted: 11 September 2007 